\title{
ESSAY
}

\section{LIFETIME EMPLOYMENT: \\ LABOR PEACE AND THE EVOLUTION OF JAPANESE CORPORATE GOVERNANCE}

\author{
Ronald J. Gilson* E Mark J. Roe**
}

In Japan, large firms' relationships with their employees differ from those prevailing in large American firms. Large Japanese firms guarantee many employees lifetime employment, and the firms' boards consist of insideremployees. Neither relationship is common in the United States.

Japanese lifetime employment is said to encourage firms and employees to invest in human capital. We examine the reported benefits of the firm's promise of lifetime employment, but conclude that it is no more than peripheral to human capital investments. Rather, the "dark" side of Japanese labor practice-constricting the external labor market-likely yielded the human capital benefits, not the "bright" side of secure employment.

What then explains the firm's promises of lifetime employment in Japan, a practice that developed following World War II, when labor was in surplus and hence economically weak? We hypothesize two political explanations, one "macro" and one "micro." The "macro" hypothesis is that a coalition of conservative and managerial interests sought lifetime employment to reduce the chances of socialist electoral victories. The "micro" hypothesis is that managers tried to defeat hostile unions and win back factories from worker occupation, firm-by-firm, by offering lifetime employment to a core of workers. Neither the "macro" nor the "micro" goals were intended to improve human capital training, but rather to reduce worker influence, either in elections or in the factory. We assess the evidence for these hypotheses.

We look at Japanese labor practices and related corporate governance institutions as "path dependent": A political decision "fixes" one institution and then the system evolves in light of that fixed institution by developing efficient complementary institutions.

\section{INTRODUCTION}

Large firms' relationships with employees differ in Japan from those prevailing in the United States. In Japan, large firms guarantee many

* Charles J. Meyers Professor of Law and Business, Stanford Law School, and Marc and Eva Stern Professor of Law and Business, Columbia Law School.

** Milton Handler Professor of Business Regulation, Columbia Law School. We thank Mark Barenberg, Harold Baum, Margaret Blair, Takeo Hoshi, Curtis Milhaupt, Kenichi Osuji, Katherine Stone, and participants in the Columbia Law School/Sloan Foundation Conference on Employees and Corporate Governance for comments on an earlier draft, Columbia Law School's Sloan Project for research support, Alex Gould for research assistance, and Saori Horikawa, Junko Oikowa, and Shinobu Yamaguchi for research assistance and translation. 
employees lifetime employment; in the United States, employment is typically at-will, although actual tenure is often long-lasting. This difference is said to be of great importance in the Japanese system: Lifetime employment for core workers is said to be at the center of Japanese corporate governance and labor relations, is said to provide an incentive for firms to invest in the workers' human capital, and is said to be central enough to be supported by other Japanese governance institutions, such as cross-shareholdings, inside boards of directors, and the main bank system. ${ }^{1}$ In the United States, in contrast, workers have neither explicit nor implicit guarantees of permanent employment and the corporate governance system rarely involves labor.

We seek here to better understand these differences by offering hypotheses about the origins and functioning of lifetime employment. Our analysis has three steps. First, lifetime employment as conventionally understood in the United States is unlikely to have had the human capital advantages claimed for it by admiring American analysts. Second, its origins lie more in politics and the struggle for labor peace than in the economics of developing human capital. Third, after it arose for political purposes, other governance institutions evolved to support efficient production. In our analysis, the firm's promise of lifetime employment (the "bright" side of Japanese labor practices) is tied to the lack of an external labor market in which employees could easily move from firm to firm (the "dark" side of Japanese labor practices), and this "dark" side probably does more of the work in encouraging employee productivity and commitment to the firm than does lifetime employment.

\section{Lifetime Employment's Purported Incentives}

The conventional view is that Japanese firms promised lifetime employment to give workers the proper incentive to invest in human capital, or that at least their promises had that as a primary effect. ${ }^{2}$ Alan Blinder states: "After all, because of the lifetime employment system, it is the core employees who ... make extensive, immobile investments [of their

1. See, e.g., Masahiko Aoki, The Japanese Firm as a System of Attributes: A Survey and Research Agenda, in The Japanese Firm: The Sources of Competitive Strength 11 (Masahiko Aoki \& Ronald Dore eds., 1994); Gerald T. Garvey \& Peter L. Swan, The Interaction Between Financial and Employment Contracts: A Formal Model of Japanese Corporate Governance, 6 J. Japanese \& Int'l. Econ. 247 (1992); Robert J. Gordon, Why U.S. Wage and Employment Behavior Differs From That in Britain and Japan, 92 Econ. J. 13 (1982); Yoshitsugu Kanemoto \& W. Bentley MacLeod, The Theory of Contracts and Labor Practices in Japan and the United States, 12 Manag. \& Dec. Econ. 159 (1991); Paul Milgrom \& John Roberts, Complementarities and Systems: Understanding Japanese Economic Organization, 9 Estudios Económicos 3 (1994); Jacob Mincer \& Yoshio Higuchi, Wage Structures and Labor Turnover in the United States and Japan, 2 J. Japanese \& Int'l Econ. 97, 110 (1988).

2. See sources cited supra note 1 . 
human capital]." ${ }^{3}$ Others tell us that "[t] he lifetime employment system, combined with a ranking hierarchy, has served to encourage skill acquisition on the part of workers and to maintain a high level of effort," 4 and go on to ask whether the United States could import lifetime employment and its benefits. ${ }^{5}$ But, we shall argue, not the firm's promise of lifetime employment alone, but its complement-a closed external labor market, limiting employees' ability to move to other firms ${ }^{6}$ - helped the Japanese labor market develop human capital investment incentives. Japanese firms may well invest in their employees' human capital, but they do so not because they have promised the employees lifetime jobs, but because their employees cannot readily move elsewhere. ${ }^{7}$ Importing lifetime employment into the United States-with many American firms promising not to fire employees-(1) would not itself directly encourage human capital investment, and (2) to work at all in encouraging human capital investment, would need its complement, the absence of an external labor market-which does the heavy lifting in Japan, but which most Americans would find unacceptable.

\section{A. The Basic Argument: Generic and Industry-specific Skills}

Human capital is conventionally divided into two categories: general, which is valuable to many employers, and firm-specific, which is valuable to only a single employer. ${ }^{8}$ In this section, we begin with general skills, said to be central to Japanese workers' attributes, particularly in their being able to move readily from one task to another. ${ }^{9}$ In the next section we look at firm-specific skills. For neither type of skill does the firm's promise to the employee of a lifetime job directly induce either the

3. Alan S. Blinder, More Like Them?, Am. Prospect, Winter 1992, at 51, 54; see also Garvey \& Swan, supra note 1, at 247-48 ("One of the most prominently cited reasons for the success of postwar Japanese firms is their ability to maintain valuable implicit agreements with their employees[, agreements] ... providing relatively stable employment ... [in a] system [that] seems to encourage both high levels of individual effort and cooperation between employees."); Mincer \& Higuchi, supra note 1, at 97 ("The starting point . . . is the proposition that intensive formation of human capital on the job is the basic proximate reason for the strong degree of worker attachment to the firm in Japan."); infra Part II.

4. Kanemoto \& MacLeod, supra note 1, at 167.

5. See id.; see also Blinder, supra note 3, at 62.

6. In internal labor markets, employees move inside the firm from job to job; in external labor markets, employees move from firm to firm.

7. Lifetime employment is sometimes understood by Japanese analysts as a two-way street: Employers promise a lifetime job, and employees promise not to leave. The latter half of the bargain seems only dimly reflected in the American literature and it is this half-or its institutional cousin, a closed external labor market-that we believe best explains the pattern of human capital investment, and which would be anathema to most Americans.

8. See Gary Becker, Human Capital 30-51 (3d ed. 1993).

9. See Masahiko Aoki, Toward an Economic Model of the Japanese Firm, $28 \mathrm{~J}$. Econ. Lit. 1, 3-14 (1990). 
employee or the employer to pay to develop the employee's human capital.

1. The Weak Incentives to Invest in Employees' General Human Capital When Labor Markets are Fluid. - Imagine an economy in which deep general skills are important: Workers need to work in teams, to develop new skills as markets change, and to run different machines as technologies and customer tastes evolve. Who will pay for employees to develop these skills? When external labor markets are fluid, firms underinvest in their employees' human capital because other firms can poach the employees after they have been trained. The poaching firms can pay the workers more, because the poachers have no training costs. True, if their employees received outside offers, the training firm could keep the employees it had trained by matching the competing firms' wage offers. But if the training firms matched the higher external wages after having already paid for the training, then they would earn nothing on their investments in training. The poaching firms and the employees would split the returns on the prior investments in training (minus the costs of relocation) for which the training firms paid; thus, the training firms would pay, but would get no return. Firms will anticipate these free-rider problems, or learn from their mistakes, and stop paying to train other firms' future employees. Employers accordingly lack the incentives to invest heavily in general human capital when their external labor markets are fluid. ${ }^{10}$

Alternatively, employees could pay for their general skills themselves, as basic human capital theory suggests, ${ }^{11}$ either directly, by paying the tuition for training programs and education, or indirectly, by accepting a lower wage while they are being trained. (This is partly the "American" solution.) When employees pay for all of their own training, employers have less reason to fear opportunism from poaching competitors or migrating employees. Employers may underinvest, but employees pay for their own general skills; or, for some, public investment in vocational education may offset underinvestment by employers.

Although employees might in general have incentives to develop their own human capital, any idea that employees at Japanese firms pay for most of their general human capital faces two problems here, one empirical and one theoretical. The empirical problem is that Japanese firms pay more of the costs of training in general skills than do American firms. ${ }^{12}$ Why do they pay more? And does the firm's promise of lifetime

10. Japanese labor markets are not fluid, but we start our analysis with fluid labor to help lead to our conclusion, that it is the constricted labor market, not the firms' promises of lifetime employment, that induces investments in human capital.

11. See Becker, supra note 8 , at 34 .

12. See Chris Tilly \& Charles Tilly, Capitalist Work and Labor Markets, in The Handbook of Economic Sociology 283, 300 (Neil J. Smelser \& Richard Swedberg eds., 1994) (citing Michael L. Dertouzos, Richard K. Lester, Robert M. Solow, and MIT Comm'n on Indus. Productivity, Made in America 81-93(1989)); see also Daron Acemoglu \& JörnSteffen Pischke, Why Do Firms Train? Theory and Evidence, 113 Q.J. Econ. 79 (1998) 
employment facilitate its investment? That is the principal question we address in this paper.

The theoretical problem is that employees are often ineffective buyers of human capital, because they are less informed than the employer about the skills needed for the future. Even if the employer offers guidance, employees may mistrust the employer, either as to the facts of what skills should be developed or, if the employee is to accept a lower wage now, as to whether the employer will compensate the employee later. And even if employees could determine the right skills in which to invest, they may be unable to afford to invest or be unwilling to invest. Credit markets for employees are imperfect, particularly for those at the beginning of their careers.

Thus, neither the employer nor the employee has the right incentives to invest in general human capital: The employer fears losing its investment if the external labor market is fluid; the employee fears losing his or her investment if the employer reneges on the promised return and often neither knows what human capital fits with the market nor has the funds to pay for that investment. Firms and employees therefore underinvest in human capital. An economy that could invest more in the right kinds of human capital would perform better over time.

2. Irrelevance of Lifetime Employment to Employees' Incentives. - Could lifetime employment solve these problems? Would firms in a fluid external labor market offer lifetime employment to align the firm's and the employee's incentives to invest in this general human capital? We believe they would not.

Suppose first that the lifetime employee pays for the general skills by taking a lower wage earlier in his or her career. Although lifetime employment protects the employee's job, the employer who offers lifetime employment is not guaranteeing that future wages will be high enough to pay the employee back for his or her investment. Lifetime employment doesn't reduce employee mistrust much if wages remain flexible, and Japanese wages are said to be even more flexible than American wages. True, the labor market protects the employee here, but the theoretical problem with lifetime employment in a perfectly fluid labor market is that the labor market always protected the employee. The employee didn't need a promise of lifetime employment in the first place because the employee could have taken his or her skills onto the labor market. Of course labor markets aren't perfect and we analyze firms' and employees' incentives in imperfect labor markets below. ${ }^{13}$ But when skills are general and labor markets frictionless, a lifetime employee will pay to get those skills, as long as he or she can sell those skills to others, even if the firm where the employee happens to be working can reduce his or her

(arguing that informational asymmetries among employers yield some incentives for firms to train their employees in general skills).

13. See infra note 88 and accompanying text. 
pay. The firm's promise of lifetime employment adds little, or nothing, to the employee's willingness to pay to acquire general skills in a fluid labor market.

Similar weaknesses afflict the familiar claim that lifetime employment encourages Japanese employees to train their own successors, because with lifetime employment the training employee does not risk that he is training his own replacement. Lifetime employment only means that his job is safe, not that future wage increases are assured. Once a trainer trains a successor, the firm could lower the trainer's variable wages (or fail to raise them enough). Once again, lifetime employment alone does not solve the labor contracting problem.

3. Irrelevance of Lifetime Employment to Employers' Incentives. - But the interesting issue in Japan is why employers pay for their employees' general human capital. Lifetime employment is said to facilitate the firm's investment, but we disagree with that view. Here's why.

If the firm guarantees employees their jobs, then, if the external labor market were fluid, it would be "heads the employees win, tails the firm loses." Heads: If an employee developed good skills at the firm's expense, the employee could jump to another firm, which could profitably pay more because it paid no training costs. If employees could signal to potential new employers when they had acquired high skills, the result would be perverse: The employer who paid for training would tend to lose its best employees and be stuck with its worst ones. In this "reverse lemons market," a firm promising lifetime employment would be committing itself to keep its least skilled employees. The firm, anticipating this unfavorable result, would invest less in its employees' general skills with lifetime employment than without it.

So why do Japanese employers invest heavily in general and industryspecific skills? We hypothesize that they invest in their employees' skills not because of the friendly Japanese institution of firms' promising their employees lifetime employment-an institution often viewed admiringly in the American literature. Rather, a dark and gloomy closing of the external labor market played a key role: Employees cannot change jobs, because the Japanese external labor market is weak, and deliberately weak. If they could change jobs easily, they could take along their general skills. ${ }^{14}$ It is the closed external labor market, not employers' promises to employees of lifetime jobs, that assures employers that they

14. Chang and Wang present a model in which low worker turnover-i.e, reduced access to an external labor market-increases a worker's incentive to invest in general human capital to avoid being fired, the consequences of which are magnified by the decreased supply of alternative jobs. See Chun Chang \& Yijiang Wang, A Framework for Understanding Differences in Labor Turnover and Human Capital Investment, 28 J. Econ. Behav. \& Org. 91 (1995). While this model links employee human capital investment to access to an external labor market, the model differs from our analysis and from Japanese labor patterns, in that in their model the employees' investment is driven by the fear of being fired; that incentive is absent when employment is lifetime. 
can earn a return if they invest in their employees' general human capital.

With the "dark" side of a weak external labor market in place, the firm can comfortably invest in its employees' general and industry-specific skills, knowing that other firms will not raid its employees: The dark side makes the employee's general human capital an asset of the training firm. Even if lifetime employment played a role here, if it also needed a closed external labor market to work well, the package would be unattractive to an American culture that values mobility.

\section{B. Firm-specific Skills}

Lifetime employment is also conventionally said to facilitate Japanese firms' investment in their employees' firm-specific human capital. But this conventional analysis also seems to us unlikely to be correct.

1. Wage Flexibility and Firm-specific Human Capital. - Suppose that the employees paid for their own firm-specific capital. If so, the firm could act opportunistically and later on "expropriate" the returns on those employees' investments.

Here's how: Firm-specific human capital is worth more to the employer than to its competitors, because the firm-specific skills are those that could help to make this firm more productive, not other firms. The employee's firm-specific skills include knowing the firm's proprietary processes or the quirks of its work-groups. Were the employee to invest in developing firm-specific skills, the employer could opportunistically pay the employee at the lower compensation level of the employee's next best job, a job at another firm that would not pay the employee for skills that the other firm could not use. Hence, the employer could reap the return from the employee's investment in herself.

Because the employee at that time would have no higher paying alternative, the employee would accept the lower wage. But the employee could anticipate this unfavorable scenario when deciding whether to pay to develop his or her own firm-specific human capital in the first place, and, fearing the firm's potential opportunism, would underinvest in those skills. ${ }^{15}$

15. Cf. Eirik G. Furubotn, A General Model of Codetermination, in Codetermination: A Discussion of Different Approaches 41, 46-48 (Hans G. Nutzinger \& Jürgen Backhaus eds., 1989) (arguing that if workers must bear the costs of developing their own skills, they may choose instead those jobs that require only general skills). The same result follows if the employer pays for the employee's firm-specific human capital, although more weakly. Because the employee must spend time to absorb the firm-specific training, the employee invests time that he could have used to develop general and marketable human capital. If the employer pays the employee up-front for this foregone investment, then the employer cannot treat the employee opportunistically as to this investment, but if the employer promises to pay up later, then the employee's time investment is firm-specific and at risk of employer opportunism. 
Firms and employees can reduce the employing firm's potential for opportunism here by developing a good reputation for paying up later, a matter we will discuss below. Here, we want to focus on the fact that lifetime employment could not credibly reduce employer opportunism, because the employer gives up very little of its power to be opportunistic by promising not to fire its employees. ${ }^{16}$ Once employees have invested in firm-specific human capital, it is not in the opportunistic firm's interest to fire them, but to exploit their wage vulnerability by lowering the employees' salaries down to the employees' value on the labor market (rather than keep the employees' wages near their value to the firm). Conventional analysis seems to miss this.

True, the firm's potential opportunism is not unlimited. If it tried to exploit too much, some disgruntled employees would become less productive or quit. ${ }^{17}$ Firms would find that they could exploit their employees only once; thereafter the employees would not pay for new or deeper skills. Even if employees invested in one big chunk at the beginning of their careers, firms that lost a reputation for fairness would find future employees uncooperative and unwilling to invest to develop their own firm-specific human capital. The point is not that these risks of firm opportunism are without cure, but that the firm's promise of lifetime employment is neither sufficient nor necessary to the cure.

2. The Firm's Investment in its Employees' Firm-specific Human Capital. We do not dispute that Japanese firms invest in their employees' human capital, but we do dispute whether the firm's promise of lifetime employment explains why. If the firm pays for the investment, it risks that an employee may quit. The firm's unwillingness to pay for the skills is induced by the employee's potential to quit, a potential that lifetime employment does not directly affect.

Once again other institutions may make firms willing to invest in human capital. For example, firms may invest in a way that allows them to pay the employees something above their opportunity-wage, thereby reducing the level of quits. The back-loaded wage scale over employees' careers fits this pattern. We have no quarrel with such models (and contribute to them below), but we again claim that lifetime employment is not critical to these models; the closed labor market in Japan might be, but this is not the Japanese institution attractive to Americans.

3. Industry-specific Human Capital. - Much purportedly firm-specific human capital is actually industry-specific human capital. ${ }^{18}$ A worker

16. Milgrom and Roberts, supra note 1, include lifetime employment as one of the barriers to opportunism.

17. See infra Part V.B., but this possibility is second-order (if relevant at all).

18. The literature focuses on the firm-specific human capital of the Japanese employee. See, e.g., Yukiko Abe, Specific Capital, Adverse Selection, and Turnover: A Comparison of the United States and Japan, 8 J. Japanese \& Int'l Econ. 272 (1994); Mincer \& Higuchi, supra note 1 . But we view many of the skills as principally industry-specific, an idea Charles Sabel develops in Ungoverned Production: An American View of the Novel 
who can use a lathe or a software system at a firm, or who has the flexibility skills associated with just-in-time automobile production, can use much the same skills at any firm in the industry. An employee with recourse to an external labor market has the incentive to acquire industryspecific skills, because even if the firm reneges, the employee "owns" the skills and can "sell" them elsewhere in the industry. ${ }^{19}$ Yet when employment is certain, but mobility impossible, employees will spend less time and money acquiring skills, because of the already-discussed risk of employer opportunism. The employer's incentive to pay for specific skills increases, but only because a closed external labor market bars employee opportunism. The employer comes to "own" the human capital. In a U.S.-style external labor market, the uncertainty of the firm's employment commitment may increase the employees' motivation to keep their industry-specific skills high.

Lifetime employment-in the sense of the employer's promise to the employee of a lifetime job-thus seems unlikely to directly induce either the employer or the employee to invest in industry-specific skills. If the employee can sell those skills to others in the industry, it is that capacity that motivates the employee to buy the industry-specific skills himself or herself, and lifetime employment adds little or nothing. And, if the employee could sell those skills in a robust external labor market-something the employee cannot do in Japan-then the firm would be deterred from paying for those industry-specific skills. (And, to be clear again here: Our view is that it is the closed external labor market that yields the human capital benefits, not the firms' promises of lifetime employment.) The hard question now is this: If lifetime employment promises from the employer do so little to enhance labor market skills investments, why did the Japanese firms promise it?

\section{Why Lifetime Employment?}

Lifetime employment resulted more from political than from human-capital based economic forces. Once the institution was in place, complementary institutions developed that served to support human capital.

\section{A. Structure of a Historical Account}

Seeking the historical roots of lifetime employment risks seeing causation where there is none. Hindsight can give the illusion of causation because events earlier in time were followed by later events. Without

Universalism of Japanese Production Methods, in Corporate Governance Today 211 (Sloan Project on Corporate Governance at Columbia Law School, May 1998). The basic skills of employees at one large firm in an industry may resemble the skills of employees at another large firm in the same industry. See Hideshi Itoh, Japanese Human Resource Management from the Viewpoint of Incentive Theory, in The Japanese Firm, supra note 1, at $233,249$.

19. But see infra note 88 and accompanying text for impeding frictions. 
more, however, random sequencing and tight causation are equally compelling. ${ }^{20}$

Similarly, the conventional claim that lifetime employment is rooted in Japanese culture ${ }^{21}$ (and needs no more explanation) is not enough. Indeed, it would be remarkable if a key economic institution were antithetical to a country's culture; either the institution would change or the culture would change. At times in the early twentieth century many midcareer Japanese employees moved to other companies, and at other times employers fired many mid-career employees. Culture and practice can diverge or converge. If culture and practice are now consistent (if we assume that lifetime employment really fits better with Japanese culture than does a fluid labor market, an assumption we doubt is correct), then one must wonder what made the two finally converge after decades of divergence.

A historical inquiry runs another risk: Complex facts allow for alternative accounts. How much labor turnover contradicts a statement that lifetime employment is present? Suppose half the workforce turns over. But then half the workforce is permanent. Is employment therefore lifetime or is it at-will? Finding that firms fired workers in Japan before World War II, as we do, presents the same problem: Were those who were fired those who, under the post-World War II pattern, would have been lifetime employees? We will not debate these facts; we will only note that the literature portrays lifetime work as central for an important segment of the labor force for postwar large Japanese firms, and we accept this as fact.

We also do not aim here to authoritatively account for lifetime employment's historical origins; that account should come from authors with other skills. We instead sketch a path-dependent account that the literature supports, with hypotheses that others will have to test.

$$
* * *
$$

History and politics shape some initial conditions from which the economy evolves. Complementary institutions develop that push the system to efficiently combine institutions, given the fixed starting point. We see Japanese labor history through a lens that highlights a need for political peace at a key moment. In examining this history, some of which is

20. See generally Michael J. Piore \& Charles F. Sabel, The Second Industrial Divide: Possibilities for Prosperity (1984); Mark J. Roe, Chaos and Evolution in Law and Economics, 109 Harv. L. Rev. 641 (1996).

21. See, e.g., James G. Abegglen, The Japanese Factory: Aspects of its Social Organization (1958). It is also possible that deep historical culture was a convenient distortion for those who would benefit from reducing employee mobility. See Andrew Gordon, The Evolution of Labor Relations in Japan: Heavy Industry, 1853-1955, at 395 (1985) ("Managers hoping to recoup their investment in training [inexperienced] workers had good reason to stress the mutual commitment of firm and employee on every possible occasion ... . They had motive, even, to invent the notion of a loyal 'permanent commitment' among workers as part of the elusive good old days ....."). 
well-known to labor scholars, some not, we observe path-dependent adaptation from political starting points.

History does not happen all at once. It does not fix a starting point and then release the economy for evolutionary development without further political influence. Economic evolution and political influence are intertwined and simultaneous. But enough happened more or less at once in postwar Japan that we can abstract a plausible starting point.

\section{B. Structure Before the End of World War II}

Stable employment is not a continuous Japanese cultural tradition. Indeed, just after the first World War, when Japanese labor markets were tight, skilled workers often changed jobs. Employment was impermanent because employees had an external labor market: Yearly turnover rates of around seventy-five percent were the norm in most industries during World War I. ${ }^{22}$ While firms tried to reduce turnover with wage and seniority policies that would become familiar in post-World War II Japan, such as year-end bonuses, seniority bonuses, and regular pay raises, these experiments failed to stymie labor turnover:

So long as economic conditions made job-switching easy, and experienced workers saw movement as the best way to advance in skill, wages penalizing skilled job switchers would be self-defeating: they would not attract the best workers. Skill rather than seniority, therefore, had to remain a fundamental determinant of a worker's income in this era, despite varied efforts to change matters. This, in turn, encouraged or allowed mobile workers to continue moving. ${ }^{23}$

The Japanese economic downturn of the 1920s led to labor surplus, and the labor surplus eroded companies' enthusiasm for seniority incentives; many firms retreated from their prior commitments to seniority bonuses, regular pay raises, or retirement funds. Firms then began to recruit inexperienced workers directly out of school and gave them on-thejob training. ${ }^{24}$ " $[\mathrm{A}]$ newly attractive pattern of long-term or career employment began to take shape . . . in the 1920s, but we must not exaggerate the extent of the change. Insecurity and short-term commitment (on

22. See Gordon, supra note 21 , at 87 . Gordon says the surveys show voluntary separations ranging from $20 \%$ to $70 \%$ of total turnover, and concludes "that the traveling worker, polishing his skills through movement from job to job, remained dominant" as the 1920 s began. Id. at 94 . Gordon emphasizes Japanese cultural features that differ from the employer paternalism that is said sometimes to explain lifetime employment. He stresses a craft pattern where skilled journeymen, licensed by guilds following apprenticeships, moved from master to master to sharpen their skills. "The footloose traveler . . . of the Meiji period, who moved with alacrity between factories and shipyards . . . [was] following time-honored customs." Id. at 22.

23. Id. at 96; see also id. at 98-101 (describing efforts to use seniority promotions during this period).

24. See id. at $63,129$. 
both sides) continue[d] to dominate. . . ."25 Voluntary mobility decreased, but the job shortage that resulted from the economic downturn best explains the employees' decreased mobility. ${ }^{26}$

Lifetime employment did not take root during this period, because employers neither promised to refrain from, nor did they actually refrain from, laying off employees during economic downturns. When jobs became scarce and an over-supply of workers ensued, "employers were ready to fire when business was slow, and seniority was no guarantee of exemption. To the contrary, they more often fired the older worker with seniority, but very likely declining skills as well. Throughout the decade, management fired workers and reduced work-force size." 27 Even when elements of lifetime employment from time to time appeared, it was temporary labor market conditions, not a long-term commitment to lifetime employment, that induced them. Quitting was common when labor was in short supply, and firings began when labor was in surplus.

Employment instability continued in the 1930s and the war years, even as better economic conditions tightened the external labor market. ${ }^{28}$ As in the tight World War I market, firms offered pay and training to induce employee loyalty, but to little avail. Skilled workers again moved between large companies. "The reemergence in the late 1930s of such mobility between large factories is a signal that policies to retain workers, some dating back to World War I or the 1920s, were of limited impact." 29

During World War II the Japanese government tried to shape the external labor market. ${ }^{30}$ In April 1939, it restricted employers from pirat-

25. Id. at 133. Aoki accepts this assessment of the period. See Aoki, supra note 1, at 30 .

26. See Gordon, supra note 21, at 139 . Taira reaches a similar conclusion: "Behind this [labor] stability in the 1920s was the generally stagnant state of employment, which culminated in the depression of 1929-1931." Koji Taira, Economic Development and the Labor Market in Japan 154 (1970). Taira also notes the difference between the reality of workforce conditions and the ideal type contemplated by the tentative structural reforms of the 1920s. He stresses the problem of investing in training when "there was no guarantee that the internally trained workers would not change jobs before the investment in their training was recouped." Id. at 158-59. Carl Mosk, Competition and Cooperation in Japanese Labour Markets 76-78 (1995), however, places more emphasis on these interwar structural changes.

27. Gordon, supra note 21 , at $139-40$.

28. Gordon reports that by 1934, skilled workers fired during the 1920 s had been rehired, and that by 1937 an acute shortage of skilled labor had developed. See id. at 156.

29. Id. at 158. Gordon recounts the experience of a company that lost $42 \%$ of its skilled work force in a single year. See also Masami Nomura, Shushin Koyoo [Lifetime Employment] 187-90 (1994) (long-term employment was tried in 1920s, but did not stick).

30. Government policies during World War II shaped many postwar Japanese institutions. See Aoki, supra note 1, at 30-31; Masahiko Aoki, Unintended Fit: Organizational Evolution and Government Design of Institutions in Japan, in The Role of Government in East Asian Economic Development 233, 236-40 (Masahiko Aoki et al. eds., 1997); Takeo Hoshi, Cleaning-up the Balance Sheets: Japanese Experience in the PostWar Reconstruction Period, in Corporate Governance in Transitional Economies: Insider 
ing other firm's workers. To hire a new employee, a firm needed government approval; to hire a skilled worker, the firm needed permission from the employee's former employer as well. By 1941, firms needed the government to approve all of their hiring, firing, and voluntary termination; in effect the government tried to freeze all workers in their existing jobs. ${ }^{31}$ But, while turnover did drop, even government directives failed to end all turnover: "Skilled workers . . . remained ready to shift jobs, even illegally, throughout World War II."32

Thus, from World War I through the end of World War II, worker mobility in external labor markets eroded labor stability when labor was tight, and employers' willingness to fire even senior workers eroded labor stability when labor markets were not tight. Employers tried but failed to build wage and seniority structures to induce workers to stay during labor shortages. Government intervention reduced but failed to stop turnover. Workers were mobile and employers poached, even when mobility and poaching were illegal.

\section{Post-World War II Labor Markets}

Labor was initially in surplus in the post-World War II Japanese labor market, just as it was in the early 1930s, but with both the size of the surplus and its consequences writ far larger in a devastated economy. ${ }^{33}$ Andrew Gordon writes that after World War II "companies quickly turned to mass dismissals. Millions lost their jobs." 34 The import of job loss was of the highest order: "Fear of starvation [was common] .... Japan lacked an effective public-welfare system, and, in 1945 or 1946, the threat of unemployment was literally a threat to survival." 35

During earlier economic setbacks, Japanese firms fired workers. The immediate post-World War II period was less favorable to lifetime employment than the pre-War period-labor was abundant, people without

Control and the Role of Banks 303 (Masahiko Aoki \& Hyung-Ki Kim eds., 1995); Hideaki Miyajima, The Transformation of Zaibatsu to Postwar Corporate Groups-From Hierarchically Integrated Groups to Horizontally Integrated Groups, $8 \mathrm{~J}$. Japanese \& Int'l Econ. 293 (1994); Yukio Noguchi, The 1940 System: Japan under the Wartime Economy, 88 Am. Econ. Rev. Papers \& Proceedings 404, 404 (1998); Tetsuji Okazaki, The Japanese Firm Under the Wartime Planned Economy, 7 J. Japanese \& Int'l Econ. 175 (1993); see also Takeo Hoshi, Evolution of the Main Bank System in Japan, in The Structure of the Japanese Economy: Changes on the Domestic and International Fronts 287 (Mitsuaki Okabe ed., 1995).

31. See Sheldon Garon, The State and Labor in Modern Japan 225 (1987); Gordon, supra note 21 , at $267,272$.

32. Gordon, supra note 21, at 274.

33. See Garon, supra note 31 , at 180.

34. Gordon, supra note 21, at 362 .

35. Id. at 363. "[A]ctual production for 1946 was down 70 percent from 1934-1936 levels. Tokyo and Osaka . . . [saw] 60 percent of all buildings destroyed . . . . Rice production was seriously deteriorating. For city dwellers, starvation was not only possible but imminent." John Price, Japan Works: Power and Paradox in Postwar Industrial Relations 38-39 (1997). 
jobs starved, and firms could hire at low wages and fire at will. Yet lifetime employment emerged during this period of labor surplus. That labor surplus and lifetime employment occurred simultaneously presents a puzzle-a puzzle that standard economic motivations fail to explain, but that politics can.

1. Labor Strife. - Organized labor in Japan gained power during the two years following World War II's end. Labor strife was common, and the American occupation authorities induced some of it. The Trade Union Law of 1945, enacted at the urging of the occupation administration, SCAP (Supreme Commander, Allied Powers), to bring democracy to Japan, guaranteed workers the right to form unions and to strike. ${ }^{36}$ Workers, fearing and experiencing mass layoffs, used both rights: They formed unions and they struck. Unions had 381,000 members when the Trade Union Law was enacted, ${ }^{37}$ more than $3,000,000$ a year later, and nearly $5,000,000$ by the end of $1946 .{ }^{38}$

These strikes threatened managers in ways beyond just halting production; workers sometimes literally took over and ran the factories without the managers. The workers paid themselves, paid the factory's other costs, and then deposited any residual in a company bank account. ${ }^{39}$ The first such "takeover" occurred in the fall of 1945 and, within the first six months of 1946, Japanese managers faced 255 such "takeover strikes." 40 After a 50-day strike at Toshiba in 1946, for example, labor won for themselves basic elements of managerial control of the factories. ${ }^{41}$

By 1947, SCAP had changed its mind about Japanese unions, coming to see then-prevailing union activity as threatening America's new anticommunist Cold War strategy. Japan's new role, in SCAP's plan, was to be a capitalist bulwark against communism. Worker control of production threatened that plan, so SCAP abandoned its pro-union policy of 1945 and prodded Japanese managers to reassert control. In 1947, Japanese unions planned a general strike, but SCAP barred them from striking and then encouraged the Japanese Parliament to ban all public sector

36. Gordon, supra note 21 , at 331-32.

37. See Mosk, supra note 26, at 95-96.

38. See Garon, supra note 31, at 238; Gordon, supra note 21, at 331.

39. See Mosk, supra note 26, at 96.

40. See Gordon, supra note 21, at 332 .

41. See Price, supra note 35, at 54; Kiyoshi Yamamoto, Toshiba Rongi-1949 [Toshiba Dispute-1949] (1983); see also Nobuhiro Hiwatari, The Origins of Japanese Lifetime Employment, in Employees' Role in Corporate Governance (Margaret Blair \& Mark J. Roe eds., forthcoming 1999) (discussing “militant labor offensives" of the late 1940s) (manuscript on file with the Columbia Law Review). But see Joe Moore, Japanese Workers and the Struggle for Power: 1945-1947, 214-15 (1983) (arguing that the violent Toshiba strike yielded the union mixed results and its ferocity deterred other firms from taking on the unions). 
employees from striking. ${ }^{42}$ American tanks supported Japanese police at least once in ousting workers. ${ }^{43}$

Toshiba's managers, encouraged by American authorities and Japanese officials who wanted an example, began an antilabor offensive in 1948, shutting down labor-controlled Toshiba factories by physically regaining control and removing key machines, dismissing workers, buying other workers' voluntary resignations, and ending labor union authority over basic management of Toshiba factories. ${ }^{44}$ SCAP's concern over Communist influence within the labor movement culminated in 1950 with the Red Purge; 12,000 employees said to be Communist Party members were fired from their jobs and barred from union activity. Existing, often communist-influenced unions were replaced with more cooperative enterprise unions. ${ }^{45}$ At the same time, socialists threatened to win legislative victories, leading to our first political hypothesis.

2. Peace as a Predicate to Production. - A plausible political strategy for managers or conservative politicians would have been to split a labor coalition by privileging one influential segment of labor through lifetime employment, in return for reducing the size of the labor force and increasing management control over the rest of production. The impetus could have come from the top down: Conservative political and business leaders decide on lifetime employment for favored sectors to diminish the chance of socialist electoral success in response to economically induced industrial restructurings. "Macro" politics could have led to a "deal" that allowed restructuring while at the same time bringing social peace, suppressing radical labor, and reducing the chance of a socialist electoral victory by privileging one sector of labor. ${ }^{46}$

The impetus also could have been "local" and "micro," which is where our second political hypothesis begins: When managers sought to rationalize production in a restructured firm, they might have privileged the surviving employees with lifetime employment, to reduce post-restructuring labor unrest. ${ }^{47}$ If many firms faced the same need to downsize, their senior managers may have decided on the same solutions, which would have gathered momentum as each firm acted. Then, in this bottom-up story, government institutions may have confirmed the norm that

42. See Gordon, supra note 21, at 332-33; Mosk, supra note 26, at 96-97.

43. See Price, supra note 35 , at 66 .

44. See Yamamoto, supra note 41.

45. See Gordon, supra note 21, at 333; Mosk, supra note 26, at 96; Price, supra note 35 , at $83-97$.

46. "In exchange for union acceptance of the performance-based wage system and limited union input in regulation of the workplace, workers received some job security .... This 'deal' had evolved at the workplace level in the 1950s," after the large layoffs that occurred in the late 1940s. Price, supra note 35, at 253. Price reports 400,000 layoffs in the private sector during only part of 1949. See id. at 76 tbl.5.

47. "Management then carried out massive layoffs and a purge of radical union leaders .... Then to reunite the [remaining] employees, management and new unions emphasized employment security ... ." Hiwatari, supra note 41 . 
many individual managers (and the surviving employees) had chosen in a deal to bring about labor peace. ${ }^{48}$ (We do not mean that there was a single, one-time, economy-wide transaction. This "deal" seems to have come out of multiple disputes, and was perhaps cemented by an emergent norm or "macro" political understanding.) This explanation is "political" in that the firms used lifetime employment not for the contractual goals of inducing skills development, but for the "political" goal of downsizing without energizing radical labor organizations. ${ }^{49}$

$$
\text { * * * }
$$

We paint a grim picture: Workers struggle to survive, workers and managers struggle to control the factories, the American occupation authorities first foster and then seek to crush strong unions, and in the end a deal is cut. Although grim, we believe this picture is realistic. A more positive spin on the same basic facts would see employees as seeking security, community, and dignity, and see managers resisting at first and then acceding to some workers' demands for security, a security that makes the favored workers more willing to cede control to management. ${ }^{50}$ Whatever spin one prefers, human capital considerations do not motivate the adoption of lifetime employment. ${ }^{51}$

***

48. For example, the "deal"-employment security in return for labor peace and cooperation-is reflected in the principles associated with the government-sponsored 1955 founding of the Japan Productivity Center. See Price, supra note 35, at 152-54.

49. Daniel Raff argues that when Henry Ford announced his famous five-dollar day for workers whose next best job opportunities paid half as well, he quite plausibly was buying them away from the Wobblies, because he feared his new assembly line method was conducive to organizational appeals from the Wobblies. See Daniel Raff, Wage Determination Theory and the Five-Dollar Day at Ford, 48 J. Econ. Hist. 387 (1988).

Support for a Japanese parallel can be seen in the following sources: Toshihiro Nishiguchi, Strategic Industrial Sourcing-The Japanese Advantage (1994) (suggesting a political component to the lifetime employment bargain, although acknowledging efforts along these lines in the interwar period); M. Shalev, Class Conflict, Corporatism and Comparison: A Japanese Enigma, in Japanese Models of Conflict Resolution 60, 71 (S.N. Eisenstadt \& Eyal Ben-Ari eds., 1990):

[During the] "offensive against labour during $1949, \ldots$ state policies (mass layoffs and the rescinding of union rights in the public sector ...) [induced] major private employers . . . to reassert their authority. Management [won] . . . showdowns with militant enterprise unions. At the same time, the big firms accepted union demands for job security and linking wages to worker [age]".

50. In return for supporting employment stability, managers got functional control over the workplace: the freedom to adjust working conditions, including employee transfer. See Takashi Araki, Flexibility in Japanese Employment Relations and the Role of the Judiciary, in Japanese Commercial Law in an Era of Internationalization 249, 269-71 (Hiroshi Oda ed., 1994).

51. The "grim" narrative resembles that of Japanese labor scholars here, with the happy view more common in American views of Japanese labor history. See Andrew Gordon, Contests for the Workplace, in Postwar Japan as History 373, 374 (Andrew Gordon ed., 1983). 
By the mid-1950s, the central features of lifetime employment were in place: fixed employment for part of the workforce, with the rest of the workforce made up of temporary workers, whose numbers could be shrunk or expanded as economic conditions demanded. The favored portion of the workforce and the company were protected from changes in the external labor market by the shock absorption capacity of temporary workers, many of whom were women. ${ }^{52}$

Encouraging workers to invest in developing firm-specific human capital need not have been the goal either of the American occupation authorities intent on building a capitalistic Japan, or of Japanese managers intent on regaining control of their factories and breaking militant unions. Japan reached a political solution to an explicitly political confrontation: control over production and management authority.

We do not dismiss economic efficiency as a selection mechanism, but at times politics "trumps" private economic goals. Afterward, we believe, conditions settle and then economic selection and evolution act on these newly "initial" conditions. Once politics defined for Japan one political "given"-lifetime employment for some workers-Japan's economic problem was to craft associated institutions that could function effectively given the politically imposed lifetime employment. Lifetime employment was more a part of the peace predicate than of the productivity supplement. ${ }^{53}$

\section{The Strength of the Political Deal}

But why did the political deal-lifetime employment and a closed external labor market-persist when the labor surplus disappeared during the economically strong 1960s? ${ }^{54}$ Why didn't employers again poach

52. See Gordon, supra note 21, at 400 ("The prominence of temporary workers in the Japanese settlement of the 1950s suggests that the group of full members made gains only at the expense of people on the margins.").

We have not tracked the history of an additional core component of Japanese labor structure: enterprise unionism, in which a company-bounded union promotes a cooperative relationship between lifetime employees and management. See, e.g., Kazuo Sugeno \& Yasuo Suwa, Labour Law Toward the 21st Century: Supporting Individual Workers in the Labour Market (Japan Int'l Labour Law Forum Paper No. 7, Mar. 1996) (on file with the Columbia Law Review). Professor Hiwatari, supra note 41, says enterprise unionism arose from the same forces that gave rise to, and were part of the same package as, the lifetime employment bargain.

53. Peace is a prerequisite to production, so deals that keep peace are not without efficiency properties. Cf. Mark J. Roe, Backlash, 98 Colum. L. Rev. 217 (1998) (discussing how political backlashes can disrupt systems otherwise thought to be efficient or lead to others designed to avoid more serious backlash). The question posed then is whether the firms' promises of lifetime employment were the "peace" predicate, as we argue seems plausible, or part of the productivity "supplement."

54. See Tadashi Hanami, Labor Relations in Japan Today 32 (1979). 
employees from competitors? Why didn't employees again become mobile?55

We offer four noncompeting hypotheses. Two see employers forbearing from laying off employees; two see employers forbearing from poaching.

The first hypothesis is that individual managers remembered the postwar labor strife and feared that if they ended lifetime employment in their firm, they would have had to confront labor but would have been isolated and likely to lose. ${ }^{56}$ Labor disputes in declining industries surely reminded managers of the potential for strife in their own. The Miike coal strike was the most famous example. The Japanese coal industry was unprofitable by 1959, and Mitsui planned large layoffs at its mines. When the union at the Miike mine, one of the most radical in Japan, resisted, management locked labor out, and in July 1960, 20,000 strikers and labor activists violently confronted 10,000 policemen..$^{57}$

The second hypothesis is that Japanese courts buttressed lifetime employment. ${ }^{58}$ Although the basic Japanese employment rule was "employment at will" with notice, ${ }^{59}$ Japanese courts responded to the "scarcity of employment opportunities in the chaotic post-War economy," 60 with an

55. Earlier employer agreements not to hire each other's employees, as well as employer efforts to persuade employees to forgo mobility, were unsuccessful. See Taira, supra note 26 , at $112-16$.

56. While this concern would be less significant during the economic expansion starting in the late 1950 s and ending with the oil shock in 1973 , it would be significant in the period of restructuring that followed. It would also account for the provisions of the 1974 Employment Insurance Law, which provided "employment adjustment benefits"subsidies - to firms trying to maintain employment levels in the face of economic adversity. See Kazuo Sugeno, Japanese Labor Law 34 (Leo Kanowitz trans., 1992). Kazuo Sugeno is frequently viewed as the leading Japanese labor law academic. One could see this managerial action as an economic agency cost to shareholders of management separated from ownership, if the risk was more of psychological pain to the manager than of labor strife that would damage the firm's stockholders.

57. See Sheldon Garon \& Mike Mochizuki, Negotiating Social Contracts, in Postwar Japan as History 145, 159-60 (Andrew Gordon ed., 1993); Price, supra note 35, at 191-218. As ultimately resolved with extensive government mediation, layoffs were allowed, but with managers both trying harder to find alternative employment for those to be terminated and increasing compensation on dismissal. See Price, supra note 35, at 216.

58. See Sugeno, supra note 56, at 395-412; Araki, supra note 50, at 251-56; Daniel H. Foote, Judicial Creation of Norms in Japanese Labor Law: Activism in the Service ofStability?, 43 UCLA L. Rev. 635, 639-65 (1996). Although these commentators see the courts as supporting the lifetime employment commitment, they do not see the courts as buttressing the no-poaching commitment.

59. Since 1896, the Japanese Civil Code has specified that an employment contract without a fixed term could be ended by either party on short notice. The Labor Standards Act, adopted in 1947, extended the notice period to 30 days but, as a matter of statutory law, did not alter the Civil Code's basic employment-at-will framework. See Sugeno, supra note 53, at 395-98.

60. Kazuo Sugeno \& Yasuo Suwa, The Japanese Internal Labour Market and its Legal Adjustments 27 (Japan Int'l Labour Law Forum Paper No. 4, Mar. 1995) (on file with the Columbia Law Review). 
"abuse of rights" doctrine that required that employers not dismiss employees "abusively." The open-ended doctrine, eventually endorsed by the Japanese Supreme Court, required that any "dismissal which is not 'objectively reasonable and socially appropriate' is ... an abuse of the right to dismiss . . . ."61

Because Japan's economy expanded during the 1960s, tests of the doctrine were few during that time; an expanding economy made uncertain how strongly firms were committed to lifetime employment and whether courts would rebuke defectors. After the 1973 oil shock, the potential bite of the judicial doctrine could be felt, however. ${ }^{62}$ Most employers kept to the implied rules of lifetime employment. When economic reversals pushed firms to downsize, firms first restricted new hiring, then farmed out excess workers to affiliates, then suspended hiring new employees, then terminated temporary workers, and then solicited early retirement. Firms laid excess workers off only after using the other downsizing tools. ${ }^{63}$ The courts adopted these tools into their notion of abusive dismissal: (1) the employer must show economic need to downsize ${ }^{64}$; (2) the employer must exhaust alternatives to layoffs, such as by transferring excess employees to affiliates; and (3) the employer must treat workers fairly and consult with them. ${ }^{5}$

Thus courts did not in our view enforce a longstanding preexisting cultural norm, but enforced the post-War practice as it had developed. A deal was made to end the post-War labor strife, and then courts made sure that one element of the deal was kept. ${ }^{66} \mathrm{Had}$ the need for labor peace not led to the deal, then Japanese courts might well have defined abusive dismissal differently. ${ }^{67}$ Thus, courts buttressed the post-War lifetime employment norm by raising the costs to any firm that wanted to change the deal.

These two hypotheses could help to explain why firms' promises to their employees of lifetime employment did not erode, but they do not explain why firms did not start to poach on one another, thereby opening up the closed labor market. Our third hypothesis is that managers feared that poaching employees mid-career from other firms risked adversely affecting the morale of the firm's existing employees and reducing the ef-

61. Araki, supra note 50, at 251 (internal citation omitted).

62. See Sugeno, supra note 56 , at $407-08$.

63. See id. at 409.

64. Professors Sugeno and Suwa note that "[a]lthough in the vast majority of cases the court eventually upholds the management decision to implement the necessary personnel reduction measures, it still examines the enterprise's business circumstances in detail and renders its own judgment on the reasonableness of the decision." Sugeno \& Suwa, supra note 60 , at 29 .

65. See Sugeno, supra note 56, at 408-10.

66. See Sugeno \& Suwa, supra note 60 , at $27,29$.

67. The judicial rule may operate here simply to slow down change. If a future consensus in Japan is reached that employers must, say, downsize to be competitive, judicial doctrine may flexibly adjust. See Sugeno, supra note 56. 
fectiveness of the internal labor market. Once firms' promises of lifetime employment were widespread in Japan, and once internal promotions became the normal way for employees to advance, a firm that brought in outsiders would risk demoralizing its own lifetime employees.

Moreover, managers may have feared that their poaching would induce other firms to retaliate and end labor understandings, leading to renewed local or national labor strife. If a vibrant external labor market reemerged, it would have threatened their firm's internal labor market. True, although firms collectively wanted a weak external labor market, free-rider effects might have undermined managers' resolve and prompted firms to poach anyway, since no firm acting alone could reopen the labor market entirely. (Hence, managers would worry mostly about how much they would demoralize current employees by bringing in someone over their heads, and not worry as much about a vibrant labor market reemerging.) But although Japanese history is hazy here, collective institutions, such as the keiretsus' presidents' council on government action, ${ }^{68}$ could have reduced this collective action problem.

One collective institution is the basis for our fourth hypothesis here. The Japanese government may have helped to destroy the external labor market. The government may have discouraged lateral hiring, thereby helping to keep the external labor market weak-a weakness that we earlier argued is critical to Japanese human capital investment. Recent accounts of Japanese corporate governance stress the government's role in designing governance institutions, ${ }^{69}$ and commentators stress the importance of joint labor-management consultations at the industrial and national levels, through industry-wide councils and study groups. ${ }^{70}$ Although we know of no explicit government efforts to shape the antipoaching principle, we do see some tantalizing evidence. ${ }^{71}$

68. In Japan, many major firms are in keiretsu groups, in which the firms and an affiliated bank own one another's stock. The presidents of the affiliated firms meet regularly in "presidents' council" meetings to discuss common problems. See Masahiko Aoki, Aspects of the Japanese Firm, in The Economic Analysis of the Japanese Firm 3, 12 (Masahiko Aoki ed., 1984); Michael L. Gerlach, Twilight of the Keiretsu? A Critical Assessment, 18 J. Japanese Stud. 79, 80-81 (1992); Charles A. Anderson, Corporate Directors in Japan, Harv. Bus. Rev., May-June 1984, at 30, 32.

69. See, e.g, Aoki, supra note 30 , at $236-40$.

70. See, e.g., Sugeno, supra note 56, at 475-77.

71. Hiwatari, supra note 41 , credits the Ministry of International Trade and Industry with a role in establishing oligopolistic structures in export industries and with inadvertently creating circumstances in which cartel-like behavior to suppress the external labor market could be maintained. More recently, the Japanese Ministry of Labor stated: "The consequences of such a policy [of allowing layoffs] would be unacceptable in Japan: Employment is the essential condition of social stability and the success of an enterprise cannot be at the expense of its employees. It's necessary to find a middle road between the traditional system [of lifetime employment], which remains at the heart of employment policy, and the new demands of the economic environment." Philippe Pons, Le gouvernement refuse d'autoriser les licenciements secs, Le Monde, Mar. 4, 1999, at 2, col. 4 (emphasis added). 
First, the Japanese government and the occupation authorities helped to design the trade-off that ultimately settled the post-War labor strife: Left-wing unions were crushed and the left curtailed politically, employment levels were reduced, management regained control over the workplace that had been lost in the late 1940s, and part of the labor force got job security. Because labor retained potential political influence despite the fact that managers recovered workplace authority in the early 1950s, the government wanted that bargain to remain stable. Second, observers recount such informal government enforcement elsewhere. Professor Aoki sees the government as enforcing an understanding that the delegated main bank monitors would bail out weak affiliated industrial firms. ${ }^{72}$ Third, head-hunting activities, a standard feature of vibrant external labor markets, were long illegal in Japan. ${ }^{73}$ Government suppression of the external labor market warrants further investigation. ${ }^{74}$

\section{A Complementary, Evolutionary Labor Market Model}

In Part I, we argued that the human capital benefits of Japan's lifetime employment cannot be understood apart from its complement-a closed labor market that shields a firm's investments in its employees' human capital from market mobility. In this Part, we fill in a gap in prevailing labor and institutional theory. We build on two major recent theoretical contributions, one from Masahiko Aoki, who stresses the need to see an entire governance system rather than one attribute, and the other from Paul Milgrom and John Roberts, who show how complementary institutions in a system can reinforce one another. Prevailing theory has a gap in that it does not yet specify how the complementary institutions arise. We seek here in this Part to close that gap.

\section{A. Complementary Institutions: Theory}

Masahiko Aoki counsels not to analyze an economic institution apart from related institutions. Complementary institutions function together

72. See Aoki, supra note 1 , at $32-33$.

73. See Japan to OK Job Placement Services, Jiji Press Ticker Serv., Nov. 14, 1996, available in LEXIS, News Library, Non-U.S. File; Rieko Saito, Calls Mounting for Job Placement Liberalization, Kyodo News Serv., Nov. 29, 1995, available in LEXIS, News Library, Non-U.S. File.

74. Each of these hypotheses, particularly the last concerning implicit government support for an anti-poaching cartel, is hard to prove. We know of no formal bureaucratic artifacts that definitively demonstrate a governmental role in enforcing an anti-poaching principle. A beginning might be the 1955 founding of the Japan Productivity Center under the guidance of the Ministry of International Trade and Industry, to enlist the support of labor in enhancing productivity and in promoting job security. See Sugeno, supra note 56, at 302; Blinder, supra note 3 , at 57 . But even the absence of such definitive artifacts (beyond our not having located references) fails to disprove the hypothesis. These are not understandings that the parties would want to document. And pervasive interaction between Japanese companies and government bureaucracies has allowed for informal sanctions that are quite subtle. 
and may work well only when all are in the same national economy. One cannot readily cherry-pick.

Paul Milgrom and John Roberts build a theory of complementary institutions, institutions whose strength arises not just directly from their own productivity, but also from making other institutions more productive. Greater training enhances productivity, and the value of that training is enhanced if the machinery is designed to be especially more productive when operated precisely. Precise machines and well-trained labor are complementary. Complementary institutions shape a development path by favoring new institutions that increase the preexisting institutions' output. ${ }^{75}$

\section{B. Complementary Institutions: Selection After Lifetime Employment Becomes Fixed}

These theories can show how labor institutions fit and interrelate with the Japanese corporate governance institutions. Aoki asserts that in Japan, the only shareholders who can readily influence managers are the shareholders who are also the firm's bankers. (That is, the firm's main bank typically owns stock in the firm, nonbank shareholders cannot easily influence the firm, and the bank with an eye on its loans does not seek pure shareholder wealth maximization.) This subdues pure shareholder influence, thereby protecting workers from the opportunism of shareholders who might want to end implicit contracts midstream. ${ }^{76}$ (Since we believe the Japanese firm makes the bulk of the human capital investment, we may not agree with Aoki on this element of the model.) But in this model, managers are not free from all accountability in that main bank contingent governance prevents managers from wandering too far from profitability. ${ }^{77}$ (That is, banks in this model do not tightly control managers, but if the contingency of sustained bad results arises, the main bank intervenes inside the firm, often taking board seats and direct influence.) The firm lacks monitoring from a pure shareholder, but Aoki states that the bank will interfere when the company performs poorly, but

75. See Milgrom \& Roberts, supra note 1, at 34; Paul Milgrom \& John Roberts, Complementarities and Fit: Strategy, Structure, and Organizational Change in Manufacturing, 19 J. Acct. \& Econ. 179, 179-206 (1995); Paul Milgrom \& John Roberts, The Economics of Modern Manufacturing: Technology, Strategy and Organization, 80 Am. Econ. Rev. 511, 518-27 (1990). Milgrom's and Roberts's analysis of Japan is deliberately static; they do not try to find the path that explains how the system took its current form: "[W]e . . . interpret the . . Japanese economy as emerging from coherent practices in an environment rife with complementarities. That . . allow[s] us to avoid issues of how the diverse decision-makers are led to pursue coherent policies and focuses instead on why the policies are coherent." Milgrom \& Roberts, supra note 1, at 19.

76. The incentives of a banker-shareholder who is a lender differ from a pure shareholder's incentives; its aversion to risk more nearly matches the preferences of employees than those of pure shareholders.

77. See Aoki, supra note 1, at 18; Garvey \& Swan, supra note 1, at 266; Milgrom \& Roberts, supra note 1, at 22-23. 
usually not otherwise. This forbearance-unless-performance-is-poor motivates both managers and workers to perform, to maintain their autonomy from banker-shareholders. ${ }^{78}$

Similarly, labor institutions fit with one another. Although lifetime employment might dilute employees' incentives to perform, this job security is offset by the large size of workers' bonuses relative to their fixed wages and by an internal tournament in which better performing employees are promoted and the others are not. ${ }^{79}$ Security in one area; insecurity in another. And these attributes help support teamwork and horizontal information sharing. Existing institutions attract their complements, because adding a complement increases the productivity of preexisting parts of the system, and the increasing returns thereby create path dependency. ${ }^{80}$

Two other features-the early retirement age and the closure of the external labor market-also are complements. Early retirement at fiftyfive is odd in isolation, because older Japanese employees, in whom the firm has invested so much, should be especially valuable. But if the firm cannot easily remove sub-par employees earlier, then the low retirement age caps lifetime employment, making it less lifetime than it first appears; the cap allows the firm to select a few stars for senior positions from its white collar managers and for leadership positions among blue collar employees; the other 55-year-old employees leave to make room for new entrants. The best employees stay, some from the managerial ranks becoming directors of the company; the others leave.

78. See Masahiko Aoki et. al., The Japanese Main Bank System: An Introductory Overview, in The Japanese Main Bank System 3, 24-26 (Masahiko Aoki \& Hugh Patrick eds., 1994).

Japanese bank shareholding may partly depend on lifetime employment. True, the main bank system also has its own historical roots, roots not directly connected with lifetime employment. Hoshi shows that postwar main bank relations grew directly out of the authoritative wartime allocation of defense companies to particular banks. See Hoshi, Cleaning-up, supra note 30 , at 307 . A question worth future investigation is whether the main bank stock ownership (1) arose independently of labor turmoil, (2) arose as a complement to lifetime employment, or (3) arose simultaneously with or after lifetime employment.

79. See Eugene Kandel \& Neil Pearson, The Value of Labor Market Flexibility (Bradley Policy Research Center Working Paper FR 95-04, University of Rochester 23, 1995) (on file with the Columbia Law Review). Prendergast explains that slow promotion in early stages of employees' careers maintains incentives to participate in the promotion tournament. Early promotion of some employees would tell others that they themselves are less likely to succeed, and would thereby dilute their incentive to perform. Slow promotion for all employees conceals this information and maintains incentives. See Canice Prendergast, Career Development and Specific Human Capital Collection, $6 \mathrm{~J}$. Japanese \& Int'l Econ. 207, 220-21 (1992). Destruction of the external labor market is also critical because an external offer could tell employees they are on their way (or not), similarly dampening incentives.

80. See Aoki, supra note 1, at 14-18; Masahiko Aoki, An Evolving Diversity of Organizational Mode and its Implications for Transitional Economies, 9 J. Japanese \& Int'l Economies 330, 350-52 (1995); Milgrom \& Roberts, supra note 1. 
Moreover, we believe it is the closure of the external labor market that does the work: "[J]apanese firms, particularly large and established ones, have bound themselves to an implicit code of not hiring former employees of other firms, particularly skilled ones . ..."11 With lifetime employment in place, it became socially plausible for business to cartelize the labor market, an action that would have been explosive in Japan in the late 1940s, and explosive in the U.S. at any time.

But where does a system's evolution begin? Any starting point is potentially arbitrary, but Japan's history helps to specify a plausible one. Lifetime employment arose as part of a politically influenced bargain, then it attracted its complements, such as the destruction of the external labor market, performance bonuses and internal tournaments with steep seniority wages, main bank contingent monitoring, promotion at the top to the inside board, and retirement at fifty-five. Japan reached a labor market equilibrium, one that it failed to reach during the interwar years, and one whose initial baseline features came about to reduce social turmoil. ${ }^{82}$

A nation that began from a different starting point, say one that like the United States valued autonomy and mobility, might evolve quite differently.

\section{How Do Labor Markets Reach Equilibrium?}

How could Japan attain an equilibrium with firms' investing in employees' industry-specific human capital? Firms in a fluid external labor market would poach from other firms that train, thereby breaking down a training equilibrium. Either employees pay for training themselves or no one pays. Because a socially worthwhile investment is not made, a nation is poorer overall unless it can break the cycle of poaching and jobhopping.

81. Masahiko Aoki, Information, Incentives, and Bargaining in the Japanese Economy 83 (1988).

82. Stable employment in the United States came from back-loaded wages based on seniority and from reputation effects that tended to bind firms in fluid labor markets. Yet, even if the American and Japanese results were identical (they are not), one would want to know how each nation reached its labor equilibrium. In the United States, rapid growth tended to make firms pay market wages (to recruit new workers) and made reputation important. In Japan, firms tried to get to that combination, but failed during the interwar years; after World War II, Japan stabilized employment to promote labor peace. From there (subsequently or simultaneously), features were added in Japan that made the equilibrium work. This difference of historical background between the United States and Japan is reflected in the different assessments of the development of the internal labor market. While the internal labor market in Japan is generally seen as supporting comity between workers and managers, some commentators see it as having developed even in the United States "to maximize the power of employers over workers." Katherine Stone, The Origins of Job Structures in the Steel Industry, in Labor Market Segmentation 27, 28 (David Gordon et al. eds., 1975). Price, supra note 35, at 259-61, appears to share Stone's view with respect to Japan. 
Our political story helps to explain how Japan did it. A direct government order to bar job-hopping would have been politically explosive. But for purposes extrinsic to the economic deal, a nation and its leading firms may agree with sectors of labor that their employment will be lifetime. In that setting, it would have been easier for employers to close the external labor market in ways that they could not have closed it previously. With the external market closed, firms more willingly invested in their employees' human capital. Once the employees were well-trained, the firms had no reason to fire them, because the employees' newly-developed human capital made them valuable to the firms. As long as the economy did not systematically degrade the value of the decades of human capital investment, the lifetime employment deal became self-enforcing: Firms did not want to fire their high-value employees, and they willingly kept the promises they made of lifetime employment.

\section{Secondary Economic Characteristics of Lifetime Employment}

For the sake of completeness, we note in this Part some potential indirect, secondary effects (or causes) of lifetime employment. None are critical to the main argument we have made.

\section{A. Lifetime Employment as a Simple Contract Term}

Lifetime employment might simply be an employee benefit with no economic function other than compensation. Or, lifetime employment could be part of mutual gift-giving: The firm promises lifetime employment and the affected employees work harder at all their tasks. ${ }^{83}$ Note though that this role is tied to effort rather than skills acquisition; it fosters employee skills only as part of an across-the-board increase in employee effort.

\section{B. Lifetime Employment as Indirectly Supporting Employees' Investment in Developing Their Own Human Capital}

To encourage investment in firm-specific human capital, a firm might develop a reputation for not reneging on paying employees a return on the employees' own investment. (This is secondary because the interesting characteristic of the Japanese system is that firms, not employees, pay for human capital.) If a firm reneged on its promised return to employees, some employees might accept the result, but others would complain and become unproductive. A firm not committed to lifetime employment could fire the grousers and keep the pliable employees. Lifetime employment makes the firm live with the grousers and therefore

83. See George Akerlof, Labor Contracts as Partial Gift Exchange, 97 Q.J. Econ. 543, 548-55 (1982); Marleen A. O’Connor, A Socio-Economic Approach to the Japanese Corporate Governance Structure, 50 Wash. \& Lee L. Rev. 1529, 1533 (1993). 
makes the firm less likely to renege on its promise to pay for the employees' investment in developing their human capital. ${ }^{84}$

Second, consider the possibility that employees invest in their own human capital. They do not know which product markets will be valuable in the future. The firm will usually have a better estimate of their product market's future, but if employees make the investment (presumably via lower wages), employees may be wary that they will invest and, if the market turns sour, the firm will lay them off. But a firm that promises the employee a lifetime job, it might be argued, could thereby make more credible its statement that the market for its product is likely to be a good market over the long run; hence, employees would arguably be more willing to invest their time (and forego wages) while developing skills for that market. ${ }^{85}$ The firm's insuring the employees' investment, by promising the employees a lifetime job even if the product market collapses, signals to employees that the firm, with better information about the product market's future, expects the skills to be valuable for a generation.

But we doubt that information signalling is a primary function of lifetime employment, because the firm's insurance is only partial, since Japanese wages are variable, with a large profit-based bonus. ${ }^{86}$ The firm might insure product-specific skills, but employees "pay" the "deductible" of potentially lower wages. And it is yet to be seen how lifetime employment will fare when product markets (and the need for the underlying technical skills) become more volatile. ${ }^{87}$ Lastly, once again, the core issue to explain here is whether lifetime employment supports the firms' investment in their employees' human capital, which we believe it would not. ${ }^{88}$

84. If this were lifetime employment's principal function, however, one would expect its incidence to vary from firm to firm, rather than follow a consistent pattern throughout a nation's economy for privileged labor sectors. The variance would be due to some firms having other means to achieve a reputation for nonexploitation, and to the fact that not all firms need high levels of firm-specific human capital.

85. Employers usually are better informed about product markets than employees. See Oliver Williamson, Markets and Hierarchies 66 (1975); Paul Willman, Opportunism in Labour Contracting: An Application of the Organisational Failures Framework, $3 \mathrm{~J}$. Econ. Behav. \& Org. 83, 86 (1982). So, if lifetime employment reduced employees' mistrust of the firm's request to "pay" for specified skills, the benefits may not be trivial.

86. See Masanori Hashimoto, Bonus Payments, On-the-Job Training, and Lifetime Employment in Japan, 87 J. Pol. Econ. 1086 (1979).

87. See Ronald Gilson, Corporate Governance and Economic Efficiency: When Do Institutions Matter?, 74 Wash. U. L.Q. 327, 343 (1996); Ronald Gilson, Reflections in a Distant Mirror: Japanese Corporate Governance Through American Eyes, 1998 Colum. Bus. L. Rev. 203, 207-08.

88. Another information asymmetry is relevant, although most relevant to the earlier analysis in fluid labor markets. Information asymmetries between firms and employees render real-world labor markets imperfect and, hence, employees cannot depend on a perfectly fluid labor market. When the employing firm is better informed about the employees' actual skill development than others in the labor market, mobility will not be perfectly smooth. While the skills involved may be general, a competitor considering hiring the training firm's employee may be unable to observe the quality of the potential 


\section{Lifetime Employment as Induced by Other Goals}

Lifetime employment might be a consequence of other labor practices. A firm may make workers multiskilled, so that the workers are unafraid of eliminating their own jobs by making technical suggestions. Multiskilled workers then move internally from job to job and appear to have lifetime employment, but the appearance of lifetime employment only derives from their multiple skills. ${ }^{89}$ Of course, the firm that has made lifetime promises for political purposes-our view of the situation-may multiskill its workers to keep them valuable over their lifetimes. Finding multiskilled employees and lifetime employment in the same economy does not reveal which direction the causality runs.

Or implicit deals may have wages low early in a career, and high later in a career. The higher-wage employees are immobile because they cannot do better elsewhere, and if the firm does not renege, employment appears to be long-term, maybe lifetime. In America this pattern gave stability to employment for several decades even without Japanese-style semiformal "lifetime" employment.

\section{Two Brief Comparisons: Germany and the United States}

A similar evolutionary story of a political decision giving rise to an institution that then evoked economic reaction and evolution can be seen in German labor and corporate history. American institutions evolved differently, probably because the need for political peace (or the manner of achieving it) was not the same in the United States.

employee's skills. As such, a potential poacher will reduce its wage offer to account for this information asymmetry: The employer will offer a wage based on the average skill level of those employees willing to leave, reflecting a mixture of higher and lower skilled workers. To that extent, even general human capital is operationally specific, and the same problems of opportunism reappear. Acemoglu and Pischke stress information asymmetries as debilitating the external labor market to explain why employers might pay for general training. See Acemoglu \& Pischke, supra note 12, at 79-82. To the extent that the market wage is lower than a skilled worker's marginal product because of information asymmetries, the employer earns a return on investing in general human capital even when paying the market wage. Bruce Greenwald also considers the connection between an employer's information advantage and the incentive to invest in general human capital. See Bruce Greenwald, Adverse Selection in the Labor Market, 53 Rev. Econ. Stud. 325, 341 (1986). Ronald Gilson and Robert Mnookin, however, rely on information asymmetry to explain general training of law firm associates. See Ronald Gilson \& Robert Mnookin, Coming of Age in a Corporate Law Firm: The Economics of Associate Career Patterns, 41 Stan. L. Rev. 567, 577-78 (1989).

Information asymmetries create a winner's curse: The poaching employer may not recruit an employee with average skill level, but only low-skilled employees whom the previous employer, with better information concerning the extent of the employee's general skills, chose not to retain. See Robert Gibbons \& Laurence Katz, Layoffs and Lemons, 9 J. Labor Econ. 351, 352-53 (1991).

89. See H. Lorne Carmichael \& W. Bentley MacLeod, Multiskilling, Technical Change and the Japanese Firm, 103 Econ. J. 142, 144 (1993). 


\section{A. German Parallels?}

Like Japanese lifetime employment, German codetermination, by which German employees select half of the board of directors in large German firms, has a political component, arising from socialist ideologies and revolutionary conflict. Its first pale features appeared during Germany's post-World War I turmoil, when Red Berlin was run by revolutionaries, as one piece of a grand compromise in 1919 between the right and the left that brought Germany temporary political stability. At the same time, a German ideology apart from interest group deals preferred a "middle way" between socialism and capitalism. ${ }^{90}$

After World War II, the occupying powers expanded codetermination in the steel and coal industries, partly at the behest of France and Britain. In 1976, after a series of strikes and seven years of public debate about conflicting models proposed by different political parties, the German Bundestag expanded codetermination, presumably to foster industrial peace. Like Japanese lifetime employment, codetermination originated not in the economics of production, nor even in the economics of firm-level corporate governance: "Rather, its purpose was to bridge the gap between capital and labor in society, or to provide social governance over private capital." 91

Because of codetermination, German firms' managers and stockholders probably reduced the flow of information into the supervisory board, had it meet less often, and minimized its functions. ${ }^{92}$ Supervisory board committees were set up, with labor less well represented on the committees than it was on the full boards, or the office of the chair (who comes from the shareholder-side) was enhanced. ${ }^{93}$ Big stockholder blocks might have persisted in Germany as a key complementary governance institution because the boards were, due to codetermination, left weak by managers and stockholders. ${ }^{94}$

\section{B. American Contrasts}

The Japanese setting in which lifetime employment arose-during the post-War suffering and starvation-contrasts with the American eco-

90. See Alan Dawley, Struggles for Justice-Social Responsibility and the Liberal State 397 (1991); Thomas Raiser, The Theory of Enterprise Law in the Federal Republic of Germany, 36 Am. J. Comp. L. 111, 117-18 (1988).

91. Katharina Pistor, Co-determination in Germany: A Socio-Political Model with Governance Externalities, in Employees' Role in Corporate Governance, supra note 41; see Alan Hyde, A Theory of Labor Legislation, 38 Buff. L. Rev. 383, 411-12 (1990).

92. Or, despite competitive pressures from a common market and a globalizing economy to energize board performance-pressures readily seen in the United StatesGerman managers and shareholders may have kept an already low-key supervisory board weak and low-key, while boards in the United States were becoming more aggressive.

93. See Pistor, supra note 91 , at 394.

94. See Mark Roe, German Codetermination and German Securities Markets, 1998 Colum. Bus. L. Rev. 167, 170-77. 
nomic setting following World War II, when the release of pent-up demand created a labor shortage. Job security in the United States was not a political issue because the external labor market and unemployment compensation protected workers. In the postwar United States, wages eventually became rigid downward. Japan, in contrast, had fixed employment for some but left wages variable.

Rather than inducing human capital investment by fixing employment and varying wages, U.S. employers are said to fix wages by foregoing downward adjustments and to vary employment by laying off employees in less profitable periods. An employer who claims bad times to justify a wage cut may be falsely portraying that its business has worsened. However, a firm that lays off employees because of bad times reduces not just its wage bill, but also its output. If the firm's business is not really bad, then layoffs also would hurt the firm, and thus the firm's representation is made credible. Although ex post the pain may be borne disproportionately by those laid off, the ex ante implicit bargain-wage rigidity with layoffs possible-makes the firm's reaction more credible in the U.S. context than wage flexibility. ${ }^{95}$

Thus, we see multiple institutional packages: In Japan, human capital requires fixed employment in a closed labor market, but wages are variable; in the United States, human capital requires fixed wages, but jobs are mobile. We explain the contrary institutional packages as due to each beginning from different starting positions. Japanese postwar poli-

95. Edward Rock and Michael Wachter state the point clearly. Asymmetric information explains the observed behavior of firms in response to cyclical changes in output:

[American] firms typically reduce employment rather than wage rates. Information about product market conditions is known to the employer but not to the employee. The employer informs its employees about product market conditions indirectly through changes in output and thus employment levels. If a firm could lower wages in response to a decline in its product market, it would have an incentive to misstate the condition of its product market in order to lower wage rates. The incentive-compatible rule is for the firm to lay off workers. Because the result of layoffs is a reduction in output, and hence a reduction in the firm's revenues and profits, such a rule eliminates the firm's incentives to misstate information.

Edward Rock \& Michael Wachter, Tailored Claims and Governance: The Fit Between Employees and Shareholders in Employees' Role in Corporate Governance, supra note 41; see also Ronald Ehrenberg \& Robert Smith, Modern Labor Economics 586 (6th ed. 1997) (discussing the positive effects of layoffs on workers' productivity); Costas Azariadis, Employment with Asymmetric Information, 98 Q.J. Econ., Supp. 1983, at 157 (same); Sanford Grossman \& Oliver Hart, Implicit Contracts, Moral Hazard, and Unemployment, 71 Am. Econ. Rev. 301 (1981) (using economic models to show that asymmetric information increases unemployment, relative to situations where marginal product information is public).

The contrast to Japan is striking. Professor Hiwatari describes the Japanese response to cyclical changes in output: "[A]fter the first oil crisis, the unions of oligopolistic firms in export industries . . . accepted wage restraint. . . . In exchange for wage moderation, large corporations maintained their commitment to employment." Hiwatari, supra note 41. 
tics fixed one piece-stable employment-and induced complementary adjustments in other parts of the labor package. For the United States, a cultural preference for mobility fixed one piece, and institutions evolved that provided economic incentives for more stability and less mobility.

\section{Today's Stress Points}

A system with complementary institutions can grow quickly because increasing one input makes the complements more productive. But complementarity has an ominous downside. When external changes devalue an attribute's contribution, the system's productivity may dramatically decline, because the other attributes of the system were built to use the nowless-important attribute. Stress points arise, and in Japan, one stress point is the firm's relation to its employees.

\section{A. Internal Labor Markets and Growth}

We have outlined a political and economic account of the Japanese labor market. First, to stabilize politics in postwar Japan and to defeat leftist unions, firms agreed to lifetime employment for a key labor sector. Second, lifetime employment, however, reduced employee incentives, and lifetime employment with an active external labor market could have especially reduced the firm's incentives to invest in employee human capital because, once trained, employees could have expropriated the employer's investment by taking another higher paying job. Third, firms reacted to lifetime employment's negative incentives by, we hypothesized, forming an implicit labor cartel, perhaps with government enforcement, to constrict the external labor market. The end of the external labor market motivated firms to pay to develop their employees' skills. Fourth, firms made the bonus a big part of compensation, with the bonus keyed to firm profitability. Firms also built internal tournaments that promoted the most motivated and skilled employees, and firms developed transfer policies to put good but redundant employees into affiliated companies and to place underperforming and redundant employees in dead-end "window" seats that punished the underperforming lifetime employees.

This model works best in expanding firms that can run promotional tournaments more successfully. Growth assures enough winners that employees want to play. Growth also allows the firm to bring in many entrylevel workers, some of whom will have the talent to become the senior managers and senior employees of the firm's future.

This last point warrants elaboration. A firm's future success depends on selecting skilled workers and managers for promotion. When first hiring, the firm can only crudely identify skill levels from the resume. Internal tournaments identify the managers who will run the firm in the next generation. The firm must recruit many to uncover the few who have the talent for the senior managerial and labor positions of tomorrow. 
Consider the crunch when growth ends for a firm with many permanent employees. The firm cannot expand; it cuts new hiring, because incumbent lifetime employees can handle the static workload. But by cutting hiring, it constricts the stream of junior employees from whom it would select its future leaders. Lifetime employees clog the promotional filters and reduce their effectiveness. ${ }^{96}$ The result: Firms lack skilled managers and employees in the right leadership positions because the tournaments become less meaningful (when no one is going upward anyway), and the firm is also less able to insure the value of workers' human capital with permanent employment at historic wage levels. The system is tense.

Our model here thus gives structure to the view that the Japanese labor model is unstable. ${ }^{97}$ The model may also give texture to the view in Japan that it has a bicycle economy-one that moves swiftly with grace but, at slow speeds, cannot maintain its balance. If promotional tournaments make lifetime employment work and if promotional tournaments function poorly when many large firms are not expanding, then many Japanese firms and the Japanese economy face problems. ${ }^{98}$

\section{B. Flexibility}

Technological change causes stress. The American and the foreign systems are both flexible, but at different levels. American governance has more "macro"-flexibility, because the external capital market presses for change and, lacking large shareholdings that facilitate credible commitments to a firm's employees, American firms have fewer commitments. Because the United States has a strong external labor market, workers pay for more of their general and industry-specific human capital, and workers lose when their skills become obsolete.

The Japanese system lacks "macro"-flexibility; its commitment to lifetime employment slows down big, rapid adjustments. But it has stronger "micro"-flexibility, in that it can induce greater commitments to human capital, which some American firms cannot induce, and Japanese employees can move and adapt well to modest technological change. Although today American macro-flexibility looks fine, it is not obvious which set of costs and benefits yields more over time. ${ }^{99}$

96. We realize that the timing of blue collar and white collar lifetime employment in Japan may have differed, as might the range of causes.

97. See Foote, supra note 58, at 699-706; Sugeno \& Suwa, supra note 60, at 44-46.

98. See, e.g., Kazuo Sugeno \& Yasuo Suwa, Labour Law Issues in a Changing Labour Market: In Search of a New Support System, in Japanese Labour and Management in Transition: Diversity, Flexibility and Participation 53 (Mari Sako \& Hiroki Sato eds., 1997) (arguing that global competition and a decreasing labor supply will lead to changes in the lifetime employment system).

99. The trade-off is less between flexibility versus commitment than it is between micro-flexibility, at the level of the worker, versus macro-flexibility, at the level of the firm. The former effectively responds to moderate change; the latter responds to radical change. See Aoki, supra note 1; Gilson, Reflections, supra note 87. 


\section{Industrial Districts and Local Employment}

Industrial districts can relieve some stress of human capital investments even where employment mobility is high. The districts can decrease the costs to the employee of moving to another firm, thereby reducing the risk of employer opportunism with respect to industry-specific human capital, and, by limiting mobility to the district, also reduce the risk of employee opportunism. Similarly, lifetime employment with a weak external labor market may encourage skills investment at times, but be undesirable in cultures like America's, which value mobility and autonomy. When skills development becomes critical in a system with a significant external labor market, we hypothesize that the "demand" for industrial districts, like Silicon Valley, will rise.

When would employees invest in industry-specific skills without getting either soft commitments from their employer of a secure job or governance rights inside the firm? An employee who can move to another firm without giving up his or her family and local social structure and without having to change residences would worry less about employer opportunism: the lower the transaction costs of changing jobs, the smaller the firm-specific component of otherwise general or industry-specific human capital. Low-cost job change works most easily when similar firms cluster.

If you left Texas Instruments [which is not in Silicon Valley] for another job, it was a major psychological move, all the way to one coast or the other, or at least as far as Phoenix. Out here [in the Valley], it wasn't that big a catastrophe to quit your job on Friday and have another job on Monday .... You just drove off in another direction on Monday morning. You didn't have to sell your house, and your kids didn't have to change schools. ${ }^{100}$

Thus, industrial districts fit industries with high industry-specific human capital needs better than they fit other industries. They reduce human capital dilemmas exactly contrary to the way prevailing in Japan: Enhancing the external labor market enhances employees' incentives to invest in their human capital, and employment is made even more impermanent by the easy switching inside the district.

In contrast, where labor is geographically immobile-as it is by choice, culture, or language in many other nations-industry-specific skills turn into firm-specific skills (because an industry-specific skill cannot be used elsewhere, since the employee cannot, or will not, move), thereby exacerbating the firm's potential for opportunism. If the mill at which the steelworkers work is the only one in town and the workers are averse to moving to another town with another steel mill, then the firm "owns" the employees' skills. If this immobility characterizes Japanese (and Ger-

100. Anna Lee Saxanian, Regional Advantage: Culture and Competition in Silicon Valley and Route 128, at 35 (1994) (quoting a Silicon Valley engineer). 
man) economic history-a cultural aversion to mobility greater than that in the United States and fewer "industrial districts"-then we have a more refined explanation for greater employee governance rights there than here. ${ }^{101}$

\section{Conclusion}

Japanese firms' promise of lifetime employment to their employees is conventionally seen as central to Japanese firms' willingness to invest heavily in their employees' skills. This presents an attractive picture for America in that an institution that employees would want would at the same time contribute to productivity. But both theoretical analysis and raw political history tell us that the story is too good to be true.

Lifetime employment originated more in postwar conservative political efforts to stymie a broad-scale labor coalition or in management's efforts to stymie factory-level unions than in the economics of human capital development. This political origin then shaped how related labor and corporate governance institutions developed in Japan, attracting complements like a closed labor market.

A firm's promise to employees of lifetime employment does not directly motivate either the firm or the employees to invest in firm-specific, industry-specific, or general skills, because it fails to eliminate employees' rational fears of firm opportunism in lowering wages or in promoting fewer people later. Japanese firms seem well suited to be opportunistic here, because Japanese wages are variable. True, a firm's opportunism could be muted by the firm's paying for the employees' skills, and payment by the firm in Japan is the human capital feature to be explained. But payment by the firm risks employee opportunism in taking away from the firm skills that the employee can use elsewhere; hence, it is the crippling of the external labor market that explains why firms in Japan were less wary than otherwise of paying to develop high skills in their employees. The weak external labor market made firms face less employee and competitor opportunism, because neither employees nor competitors can appropriate the returns on the firm's investments. Thus, optimistic accounts of Japanese labor relations-that the sunny-side of lifetime employment induces employees and firms to invest better in generic and firm-specific skills-are exaggerated. More plausibly, if any factor is in play besides an expanding economy for most of the postwar period, it is the "dark" side of a limited labor market that accounts for the greater investment.

101. The politics of codetermination in Germany fits our production model: Geographic immobility rendered industry-specific human capital firm-specific and thereby heightened the demand for employee involvement in corporate governance. This heightened demand could have expressed itself in contract negotiations and in political demands as well. We could then change our model-with politics independent of the production-to make production affect politics. 